\title{
DRY MATTER OF CYMBOPOGON MARTINI STAPF AND NUTRIENT STATUS OF THE PLANT AND SOIL AS INFLUENCED BY FLY ASH AND VERMICOMPOST
}

\author{
G SHARON ROSE $^{\mathbf{1}}, \mathrm{K}^{\text {VENKATALAXMI }}{ }^{2}$, K SADHANA $^{\mathbf{3}} \boldsymbol{\&}$ P SRINIVAS $^{4}$ \\ 1, 2,4 Department of Plantation, Spices, Medicinal and Aromatic Crops, College of Horticulture, Sri Konda Laxman \\ Telangana State Horticultural University, Rajendranagar, Hyderabad, Telangana, India \\ ${ }^{3}$ Department of Horticulture, College of Horticulture, Kerala Agricultural University, Vellanikkara, Kerala, India
}

ABSTRACT
Different levels of fly ash and vermicompost in soil were tried and their effect on dry matter (\%), plant $N$, P and
$K$ content (\%) in Cymbopogon martini Stapf and available soil $N, P$ and $K(\mathrm{~kg} / \mathrm{ha})$ were observed for a period of two
harvests during $2014-2015$ at CIMAP, Boduppal, Hyderabad. The perusal of the data revealed that treatment $T_{7}$ with 6
t/ha of fly ash +4 t/ha of vermicompost recorded maximum dry matter content $(50.95 \%$ and $40.76 \%)$, plant $N(2.14 \%$ and
$2.03 \%), P(0.32 \%$ and $0.30 \%)$ and $K(4.23 \%$ and $3.79 \%)$ content at both harvests. The treatment $T_{1}$ receiving 10 t/ha of
vermicompost recorded maximum soil available $N(414.61 \mathrm{~kg} / \mathrm{ha}$ and $372.42 \mathrm{~kg} / \mathrm{ha})$ and $P(29.32 \mathrm{~kg} / \mathrm{ha}$ and $21.56 \mathrm{~kg} / \mathrm{ha})$ at
both harvests. Maximum soil available $\mathrm{K}(558.25 \mathrm{~kg} / \mathrm{ha}$ and $542.13 \mathrm{~kg} / \mathrm{ha})$ was recorded by the treatment $T_{11}$ receiving 10
t/ha of fly ash alone. From the investigation, it can be concluded that 6 t/ha of fly ash with 4 t/ha of vermicompost as best
treatment as it recorded maximum dry matter and nutrient status in palmarosa, followed by treatments $T_{8}, T_{9}, T_{10}$ and $T_{11}$
that were on par with the treatment $T_{7}$ for dry matter and nutrient status in palmarosa.
KEYWORDS: Fly Ash, Vermicompost, Palmarosa, Dry Matter \& $\mathrm{N}, P, \mathrm{~K}$

Received: Jun 30, 2017; Accepted: Jul 15, 2017; Published: Jul 19, 2017; Paper Id.: IJASRAUG201743

\section{INTRODUCTION}

Palmarosa (C. martini Stapf var. motia), an aromatic perennial grass, also referred as East Indian geranium or Russa grass is native of subtropical India, known for its essential oil for a long time. Palmarosa oil has been distilled commercially for more than 100 years in India. Oil has many industrial applications viz., perfumes, cosmetics, bath products, medicinal, household purposes and flavouring tobacco. The use of oil is reputed in aromatherapy. It is a colourless to pale yellow volatile oil possessing a sweet scented rose like aroma with high content of compounds called geraniol (70.1-85.3\%) and geranyl acetate (4.3-14.8\%). The oil is extracted from inflorescence (2\%), leaf lamina (1.4\%), whole herb $(0.75 \%)$ and leaf sheath (0.33\%) (Rajeswara Rao et al., 2009).

Plant nutrition is one of the important factors that control growth and development. Plant nutrition through organic farming is gaining momentum especially in the cultivation of medicinal and aromatic plants for quality of produce that gets premium price. In addition to premium price, application of nutrients through organic sources like vermin compost and fly ash will be cost effective in palmarosa production. Integrated use of fly ash, organic and inorganic fertilizers saved N, P, and K fertilizers to the range of 45.8, 33.5 and $69.9 \%$, respectively and gave higher fertilizer use efficiency than chemical fertilizers alone or combined use of organic and chemical fertilizers in a ricegroundnut cropping system (Mittra et al, 2003).

Fly ash is a by-product of pulverized coal fired thermal power stations and the disposal of fly ash is a serious 
issue. It has been proved that fly ash can be advantageously used as a source of essential plant nutrients that promotes plant growth in aromatic grasses. It provides essential plant micro-nutrients like $\mathrm{Fe}, \mathrm{Mn}, \mathrm{Zn}, \mathrm{Cu}, \mathrm{Co}, \mathrm{B}, \mathrm{Mo}$ and macro-nutrients like $\mathrm{P}, \mathrm{K}, \mathrm{Ca}, \mathrm{Mg}$ and $\mathrm{S}$ beneficial for plant growth and increases the yield in various crops by $20-25 \%$ with high nutrition value. Amendments of fly ash with nutrient rich vermicompost may improve the soil condition and availability of nutrients thereby enhancing crop production. Significantly superior yield parameters of wheat were found on application of recommended dose of NPK + FYM 10t/ha and the treatment was at par with NPK + Vermicompost + fly ash combination for the characters studied (Yavarzadeh and Shamsadini, 2012).

The experiment is an attempt to promote cultivation of aromatic plants using low cost inputs like fly ash and vermicompost and to reduce the use of chemical fertilizers. Considering the importance of the crop and facts of fly ash and vermicompost, the present experiment was conducted to exploit the effect of fly ash and vermicompost on herb yield, essential oil content and composition in palmarosa.

\section{MATERIALS AND METHODS}

The field experiment was carried out at Central Institute of Medicinal and Aromatic Plants, Regional Centre, Boduppal, Hyderabad during 2014-2015. The experimental site is situated at latitude of $17^{0} 32^{\prime} \mathrm{N}$ and longitude of $78^{0} 38^{\prime} \mathrm{E}$ that falls in semiarid tropical climate. There were 13 treatments arranged in randomized block design with three replications each. The Trishna variety of palmarosa plants were spaced at $60 \mathrm{~cm} \mathrm{X} 45 \mathrm{~cm}$. The treatments includedT $1-\mathrm{F}_{0}$ $+\mathrm{V}_{10}-\mathrm{Fly} \operatorname{ash}(0 \mathrm{t} / \mathrm{ha})+$ vermicompost $(10 \mathrm{t} / \mathrm{ha}), \mathrm{T}_{2}-\mathrm{F}_{1}+\mathrm{V}_{9}-$ Fly ash $(1 \mathrm{t} / \mathrm{ha})+$ Vermicompost $(9 \mathrm{t} / \mathrm{ha}), \mathrm{T}_{3}-\mathrm{F}_{2}+\mathrm{V}_{8}-$ Fly ash (2 t/ha) + Vermicompost (8 t/ha), $T_{4}-F_{3}+V_{7}-$ Fly ash (3t/ha) + Vermicompost $(7 \mathrm{t} / \mathrm{ha}), \mathrm{T}_{5}-\mathrm{F}_{4}+\mathrm{V}_{6}-\mathrm{Fly}$ ash $(4$ $\mathrm{t} / \mathrm{ha})+$ Vermicompost $(6 \mathrm{t} / \mathrm{ha}), \mathrm{T}_{6}-\mathrm{F}_{5}+\mathrm{V}_{5}-$ Fly ash $(5 \mathrm{t} / \mathrm{ha})+$ Vermicompost $(5 \mathrm{t} / \mathrm{ha}), \mathrm{T}_{7}-\mathrm{F}_{6}+\mathrm{V}_{4}-$ Fly ash $(6 \mathrm{t} / \mathrm{ha})+$ Vermicompost (4t/ha), $T_{8}-F_{7}+V_{3}-$ Fly ash $(7 \mathrm{t} / \mathrm{ha})+$ Vermicompost $(3 \mathrm{t} / \mathrm{ha}), \mathrm{T}_{9}-\mathrm{F}_{8}+\mathrm{V}_{2}-$ Fly ash $(8 \mathrm{t} / \mathrm{ha})+$ Vermicompost (2t/ha), $T_{10}-F_{9}+V_{1}-$ Fly ash $(9 t / h a)+$ Vermicompost $(1 \mathrm{t} / \mathrm{ha}), \mathrm{T}_{11}-\mathrm{F}_{10}+\mathrm{V}_{0}-$ Fly ash (10 t/ha) + Vermicompost (0 t/ha), $\mathrm{T}_{12}-$ Normal dose of fertilizer (100:40:40 kg/ha), $\mathrm{T}_{13}-$ Zero fertilizer (control).

Before treatment imposition the available N, P and $\mathrm{K}$ in soil were $297.00 \mathrm{~kg} / \mathrm{ha}, 22.6 \mathrm{~kg} / \mathrm{ha}$ and $219.28 \mathrm{~kg} / \mathrm{ha}$, respectively. Treatments were imposed on standing crop after a harvest. The first irrigation was given immediately after treatment imposition and the subsequent irrigations were given as and when required depending upon soil and weather conditions. Weeding was done as and when required. The harvest was taken after 90 days, when the crop was in full bloom. Five plants were selected at random from each replication and a total of fifteen plants per treatment and tagged for recording observations. The data on dry matter $\%$ were recorded at monthly intervals, while the data on soil available N, P and $\mathrm{K}$ and plant N, P and $\mathrm{K}$ content were recorded at each harvest i.e at 90 days and 180 days, respectively. The data was statistically analyzed by method of analysis of variance using Randomized Block Design (RBD) as described by Panse and Sukhatme (1985).

\section{Dry Matter (\%)}

Two hundred grams of fresh herb is taken and dried in hot air oven at $70^{\circ} \mathrm{C}$ till constant weight is obtained. The weight of the dry herb was divided by the weight of the fresh herb and multiplied by 100 to get dry matter percentage.

Dry matter $\%=\frac{\text { Dry weight of the herh }(\mathrm{g})}{\text { Fresh weight of the herb (g) }} \times 100$ 


\section{N, P, K of Plant (\%)}

The plant samples were collected, decontaminated, dried and analyzed after each harvest at CIMAP laboratory, Boduppal, Hyderabad.

The procedures adopted for the analysis of nutrients are briefly outlined below.

\section{Digestion of Plant Samples}

Half gram of oven dried and powdered leaf sample was taken in $50 \mathrm{ml}$ conical flasks for digestion using diacid (9:4; Nitric acid: Perchloric acid). $10 \mathrm{ml}$ of the diacid mixture was added and was allowed overnight for pre-digestion and then heated at $100^{\circ} \mathrm{c}$ for an hour and $250^{\circ} \mathrm{c}$ until colorless clear solution obtained. It was cooled and the volume was made up to $100 \mathrm{ml}$ with distilled water. The same was used for estimation of $\mathrm{P}$ and $\mathrm{K}$.

For nitrogen estimation, $0.5 \mathrm{~g}$ plant sample was digested using $2 \mathrm{~g}$ digestion mixture consisting of copper sulphate, potassium sulphate in 5:1 ratio and $10 \mathrm{ml}$ of sulphuric acid on the digestion unit at $450^{\circ} \mathrm{C}$ till the light green color appears.

\section{Estimation of Nitrogen}

Nitrogen was determined by Kjeldhal's method. Half gram digested plant sample was distilled using microKjeldhal unit and the liberated ammonia was trapped in boric acid containing mixed indicator and titrated against $0.01 \mathrm{~N}$ $\mathrm{H}_{2} \mathrm{SO}_{4}$. The nitrogen content in the leaves was expressed in per cent.

\section{Estimation of Phosphorus}

Diacid digested plant sample was used for the determination of total phosphorus by developing vanadomolybdo phosphoric yellow colour. The intensity of yellow colour was read in spectrometer (Systronics UV-VIS Spectrophotometer 118) at $470 \mathrm{~nm}$. The phosphorus content in the leaves was expressed in per cent.

\section{Estimation of Potassium}

Potassium content was determined by a microprocessor based flame photometer using specific filter and LPG flame. Diluted diacid digest was fed to atomizer through capillary tube and concentration was directly read on the display monitor. Per cent potassium content on dry weight basis was calculated. The potassium content in the leaves was expressed in per cent.

\section{N, P, K of Soil (Kg/ha)}

The collected soil samples were processed (dried, grinded and sieved) before they were analyzed before treatment imposition and after each harvest. The work was carried out at CIMAP laboratory, Boduppal, Hyderabad.

\section{Estimation of Nitrogen}

Available $\mathrm{N}$ was estimated by alkaline permanganate method. The available $\mathrm{N}$ in soil was expressed in $\mathrm{kg} / \mathrm{ha}$.

\section{Estimation of Phosphorous}

The available $\mathrm{P}$ is extracted using Olsen's extract ant which is added to two grams of soil. To the extract, a drop of p-nitro phenol and reagent B (reagent A $[12 \mathrm{~g} / 200 \mathrm{ml}$ of ammonium molybdate $+0.2908 \mathrm{~g} / 100 \mathrm{ml}$ of antimony potassium tartarate $+1000 \mathrm{ml}$ of $2.5 \mathrm{M} \mathrm{H}_{2} \mathrm{SO}_{4}$ and made up to 2 litres] $+1.056 \mathrm{~g} / 100 \mathrm{ml}$ ascorbic acid) were added. 
According to the intensity of the colour of the contents the absorbance value was recorded using spectrophotometer and incorporated into the standard graph which gave the concentration of $\mathrm{P}$. The available $\mathrm{P}$ in soil was expressed in $\mathrm{kg} / \mathrm{ha}$.

\section{Estimation of Potassium}

The available soil $\mathrm{K}$ is estimated by flame photometry. The available $\mathrm{K}$ in soil was expressed in $\mathrm{kg} / \mathrm{ha}$.

\section{RESULTS AND DISCUSSION}

\section{Dry Matter of Palmarosa as Influenced by Fly Ash and Vermicompost}

The dry matter of palmarosa for the treatments has differed significantly due to the application of fly ash and vermicompost. The treatment $\mathrm{T}_{7}(\mathrm{FA} 6 \mathrm{t} / \mathrm{ha}+\mathrm{VC} 4 \mathrm{t} / \mathrm{ha})$ has recorded maximum dry matter content $(50.95 \%$ and $40.76 \%)$ at 90 days and 180 days, respectively. The results are in accordance with the findings of Deshmukh et al. (2000) who found beneficial effects of fly ash application on production of dry matter in wheat crop. Dry matter accumulation increased significantly when treated with 4 t/ha of vermicompost in pearlmillet (Choudhary et al., 2014). The maximum dry matter recorded by the treatment $\mathrm{T}_{7}(\mathrm{FA} 6 \mathrm{t} / \mathrm{ha}+\mathrm{VC} 4 \mathrm{t} / \mathrm{ha}$ ) may be due to enhanced biomass production as a result of balanced supply of nutrients and favorable soil conditions by fly ash and vermicompost application. However in the second crop, the plant growth and herb yield were affected by low temperatures of winter season. The result is supported by Pandu Sastry et al. (2014) in citronella and Pandu Sastry et al. (2015) in palmarosa where they reported that the growth and herb yield are more in the crop raised during October-December when compared to January-March. This is due to the fact that the plant growth was favored by the moderate temperature throughout the crop period October-December.

\section{Nutrient Status of Palmarosa as Influenced by Fly Ash and Vermicompost}

Similarly the nitrogen, phosphorous and potassium content of plant was significantly influenced by the treatments and the data are presented in the table-2. The treatment $\mathrm{T}_{7}(\mathrm{FA} 6 \mathrm{t} / \mathrm{ha}+\mathrm{VC} 4 \mathrm{t} / \mathrm{ha})$ has recorded significant maximum plant nitrogen $(2.14 \%$ and $2.03 \%)$, phosphorous $(0.32 \%$ and $0.30 \%)$ and potassium content $(4.23 \%$ and $3.79 \%)$ at harvest-I and harvest-II, respectively. Maximum plant N, P and K contents as recorded with the treatment $\mathrm{T}_{7}(\mathrm{FA} 6 \mathrm{t} / \mathrm{ha}+\mathrm{VC} 4 \mathrm{t} / \mathrm{ha})$ might be due to the combined application of nutrient rich fly ash and vermicompost to the soil that increased the uptake and resulted in maximum plant N, P and K content. Highest content of nutrients were recorded in green gram with increasing levels of fly ash up to $10 \mathrm{t} / \mathrm{ha}$ (Bhaisare et al., 2000). P and K content of sudan grass and oats increased with graded levels of fly ash incorporation in soil up to $100 \mathrm{~g} / \mathrm{Kg}$. The phosphorous and potassium content in pod and haulm was increased with the application of $30 \mathrm{t} / \mathrm{ha}$ of fly ash in groundnut (Dange and Nalge, 2010). The application of vermicompost up to $4 \mathrm{t}$ /ha significantly increased total uptake of N, P and K in fenugreek (Verma et al., 2014). However, the treatment $\mathrm{T}_{6}, \mathrm{~T}_{8}, \mathrm{~T}_{9}, \mathrm{~T}_{10}$ and $\mathrm{T}_{11}$ were on par with the treatment $\mathrm{T}_{7}$ for dry matter, plant $\mathrm{N}, \mathrm{P}$ and $\mathrm{K}$ content at both the harvests. The dry matter, plant N, P and K increased with increase in the fly ash doses up to 6 t/ha of fly ash level. Beyond this level though the treatments showed maximum dry matter, plant $\mathrm{N}, \mathrm{P}$ and $\mathrm{K}$ content and there was no significant difference up to $10 \mathrm{t} /$ ha of fly ash application. The vermicompost had significant improvement in dry matter, plant $\mathrm{N}$, $\mathrm{P}$ and $\mathrm{K}$ content up to $5 \mathrm{t} / \mathrm{ha}$ beyond which it had no significant improvement as the nitrogen supplied through vermicompost reaches a level of luxury consumption. This may also be due to the lower doses of fly ash.

\section{Nutrient Status of Soil as Influenced by Fly Ash and Vermicompost}

The N, P and K status of soil was influenced after the application of fly ash and vermicompost. The treatments showed significant differences for $\mathrm{N}, \mathrm{P}$ and $\mathrm{K}$ of soil due to different levels of fly ash and vermicompost and the data are 

Influenced by Fly Ash and Vermicompost

presented in Table-3. Among the different treatments of fly ash and vermicompost, the treatment $\mathrm{T}_{1}(\mathrm{FA} 0 \mathrm{t} / \mathrm{ha}+\mathrm{VC} 10$ $\mathrm{t} / \mathrm{ha})$ has recorded significant maximum soil available nitrogen at harvest-I (414.61 kg/ha) and harvest-II (372.42 kg/ha). Also, the treatment has recorded maximum soil available phosphorous at harvest-I (29.32 kg/ha) and harvest-II (21.56 $\mathrm{kg} / \mathrm{ha}$ ). This may be due to vermicompost that holds and retains $\mathrm{N}$ losses and might have helped in solubilization of P. Similar results were noticed by Singh and Wasnik (2013). Available N and P were greater in postharvest soils that received vermicompost. Maximum soil available potassium was recorded with the treatment $\mathrm{T}_{11}(\mathrm{FA} 10 \mathrm{t} / \mathrm{ha}+\mathrm{VC} 0 \mathrm{t} / \mathrm{ha})$ at harvestI (558.25 kg/ha) and harvest-II (542.13 kg/ha). Rai et al (2012) reported improvement of soil available $\mathrm{K}$ on fly ash application.

\section{CONCLUSIONS}

The treatment $\mathrm{T}_{7}$ with $6 \mathrm{t} / \mathrm{ha}$ of fly ash and $4 \mathrm{t} /$ ha of vermicompost has resulted in significantly higher dry matter, N, P and K content of plant implying good plant growth with high herb yield and essential oil yield. Treatment $\mathrm{T}_{7}$ (FA 6 $\mathrm{t} / \mathrm{ha}+\mathrm{VC} 4 \mathrm{t} / \mathrm{ha})$ when compared with $\mathrm{T}_{11}(\mathrm{FA} 10 \mathrm{t} / \mathrm{ha}+\mathrm{VC} 0 \mathrm{t} / \mathrm{ha}), \mathrm{T}_{11}(\mathrm{FA} 10 \mathrm{t} / \mathrm{ha}+\mathrm{VC} 0 \mathrm{t} / \mathrm{ha})$ is cost effective as it has no vermicompost. But, fly ash alone at higher levels may affect soil health in a short period of 2-3 years. Therefore, $\mathrm{T}_{7}(\mathrm{FA}$ $6 \mathrm{t} / \mathrm{ha}+\mathrm{VC} 4 \mathrm{t} / \mathrm{ha}$ ) with low levels of fly ash in combination with vermicompost is recommended in case of palmarosa, which is a perennial crop cultivated for 4-5 years. The treatment $\mathrm{T}_{12}$ (RDF) recorded significantly lower values while the treatment $\mathrm{T}_{13}$ (Zero fertilizer) recorded least values for dry matter, plant $\mathrm{N}, \mathrm{P}$ and $\mathrm{K}$ content available soil $\mathrm{N}, \mathrm{P}$ and $\mathrm{K}$ at harvests-I and II.

Keeping in view the importance of organically produced oil of palmarosa and the premium price it is being offered in the international trade, cultivation of palmarosa with cheap organic sources like fly ash may be recommended.

Table 1: Effect of Fly Ash and Vermicompost at different Combinations on Plant Dry Matter (\%)

\begin{tabular}{|l|c|c|}
\hline \multirow{2}{*}{ Treatments (T) } & \multicolumn{2}{c|}{ Dry Matter (\%) } \\
\cline { 2 - 3 } & Harvest I & Harvest II \\
\hline $\mathrm{T}_{1}-\mathrm{FA}+\mathrm{VC}(0 \mathrm{t} / \mathrm{ha}+10 \mathrm{t} / \mathrm{ha})$ & 40.45 & 32.13 \\
\hline $\mathrm{T}_{2}-\mathrm{FA}+\mathrm{VC}(1 \mathrm{t} / \mathrm{ha}+9 \mathrm{t} / \mathrm{ha})$ & 42.30 & 32.87 \\
\hline $\mathrm{T}_{3}-\mathrm{FA}+\mathrm{VC}(2 \mathrm{t} / \mathrm{ha}+$ 8t/ha) & 43.60 & 34.64 \\
\hline $\mathrm{T}_{4}-\mathrm{FA}+\mathrm{VC}(3 \mathrm{t} / \mathrm{ha}+7 \mathrm{t} / \mathrm{ha})$ & 45.50 & 36.33 \\
\hline $\mathrm{T}_{5}-\mathrm{FA}+\mathrm{VC}(4 \mathrm{t} / \mathrm{ha}+6 \mathrm{t} / \mathrm{ha})$ & 47.34 & 37.47 \\
\hline $\mathrm{T}_{6}-\mathrm{FA}+\mathrm{VC}(5 \mathrm{t} / \mathrm{ha}+5 \mathrm{t} / \mathrm{ha})$ & 50.70 & 40.42 \\
\hline $\mathrm{T}_{7}-\mathrm{FA}+\mathrm{VC}(6 \mathrm{t} / \mathrm{ha}+4 \mathrm{t} / \mathrm{ha})$ & 50.95 & 40.76 \\
\hline $\mathrm{T}_{8}-\mathrm{FA}+\mathrm{VC}(7 \mathrm{t} / \mathrm{ha}+3 \mathrm{t} / \mathrm{ha})$ & 49.97 & 40.28 \\
\hline $\mathrm{T}_{9}-\mathrm{FA}+\mathrm{VC}(8 \mathrm{t} / \mathrm{ha}+2 \mathrm{t} / \mathrm{ha})$ & 50.17 & 40.22 \\
\hline $\mathrm{T}_{10}-\mathrm{FA}+\mathrm{VC}(9 \mathrm{t} / \mathrm{ha}+1 \mathrm{t} / \mathrm{ha})$ & 50.86 & 40.60 \\
\hline $\mathrm{T}_{11}-\mathrm{FA}+\mathrm{VC}(10 \mathrm{t} / \mathrm{ha}+0 \mathrm{t} / \mathrm{ha})$ & 50.71 & 40.70 \\
\hline $\mathrm{T}_{12}-\mathrm{RDF}(100-40-40 \mathrm{NPK}$ Kg/ha) & 40.76 & 32.60 \\
\hline $\mathrm{T}_{13}-\mathrm{Zero}$ fertilizer $(\mathrm{control})$ & 35.15 & 29.36 \\
\hline SE $\mathbf{m} \pm$ & 0.34 & 0.24 \\
\hline CD at 5\% & 1.01 & 0.70 \\
\hline
\end{tabular}

FA - Fly ash, VC - Vermicompost, RDF - Recommended Dose of Fertilizer

Table 2: Effect of fly Ash and Vermicompost at Different Combinations on Plant N, P and K (\%)

\begin{tabular}{|l|c|c|c|c|c|c|}
\hline \multirow{2}{*}{ Treatments (T) } & \multicolumn{5}{|c|}{ N, P and K of Plant (\%) } \\
\cline { 2 - 6 } & \multicolumn{4}{|c|}{ Harvest-I } & \multicolumn{3}{c|}{ Harvest-II } \\
\cline { 2 - 6 } & N & P & K & N & P & K \\
\hline
\end{tabular}




\begin{tabular}{|c|c|c|c|c|c|c|}
\hline \multicolumn{7}{|c|}{ Table 2: Contd } \\
\hline $\mathrm{T}_{1}-\mathrm{FA}+\mathrm{VC}(0 \mathrm{t} / \mathrm{ha}+10 \mathrm{t} / \mathrm{ha})$ & 1.68 & 0.24 & 2.38 & 1.62 & 0.20 & 2.21 \\
\hline$T_{2}-F A+V C(1 t / h a+9 t / h a)$ & 1.75 & 0.25 & 2.39 & 1.68 & 0.23 & 2.31 \\
\hline $\mathrm{T}_{3}-\mathrm{FA}+\mathrm{VC}(2 \mathrm{t} / \mathrm{ha}+8 \mathrm{t} / \mathrm{ha})$ & 1.75 & 0.27 & 2.53 & 1.67 & 0.23 & 2.47 \\
\hline $\mathrm{T}_{4}-\mathrm{FA}+\mathrm{VC}(3 \mathrm{t} / \mathrm{ha}+7 \mathrm{t} / \mathrm{ha})$ & 1.89 & 0.28 & 2.82 & 1.85 & 0.24 & 2.75 \\
\hline$T_{5}-F A+V C(4 t / h a+6 t / h a)$ & 1.93 & 0.28 & 2.86 & 1.87 & 0.25 & 2.77 \\
\hline $\mathrm{T}_{6}-\mathrm{FA}+\mathrm{VC}(5 \mathrm{t} / \mathrm{ha}+5 \mathrm{t} / \mathrm{ha})$ & 2.11 & 0.30 & 3.79 & 1.98 & 0.29 & 3.74 \\
\hline $\mathrm{T}_{7}-\mathrm{FA}+\mathrm{VC}(6 \mathrm{t} / \mathrm{ha}+4 \mathrm{t} / \mathrm{ha})$ & 2.14 & 0.32 & 4.23 & 2.03 & 0.30 & 3.79 \\
\hline$T_{8}-F A+V C(7 t / h a+3 t / h a)$ & 2.10 & 0.31 & 4.20 & 1.97 & 0.29 & 3.71 \\
\hline $\mathrm{T}_{9}-\mathrm{FA}+\mathrm{VC}(8 \mathrm{t} / \mathrm{ha}+2 \mathrm{t} / \mathrm{ha})$ & 2.08 & 0.30 & 4.09 & 1.95 & 0.29 & 3.68 \\
\hline $\mathrm{T}_{10}-\mathrm{FA}+\mathrm{VC}(9 \mathrm{t} / \mathrm{ha}+1 \mathrm{t} / \mathrm{ha})$ & 2.06 & 0.30 & 3.85 & 1.94 & 0.29 & 3.67 \\
\hline $\mathrm{T}_{11}-\mathrm{FA}+\mathrm{VC}(10 \mathrm{t} / \mathrm{ha}+0 \mathrm{t} / \mathrm{ha})$ & 1.98 & 0.29 & 3.78 & 1.92 & 0.28 & 3.64 \\
\hline $\mathrm{T}_{12}-\mathrm{RDF}(100-40-40 \mathrm{NPK} \mathrm{Kg} / \mathrm{ha})$ & 1.70 & 0.22 & 2.36 & 1.15 & 0.18 & 1.96 \\
\hline $\mathrm{T}_{13}-$ Zero fertilizer (control) & 1.12 & 0.16 & 1.93 & 1.04 & 0.14 & 1.78 \\
\hline SE $\mathbf{m} \pm$ & 0.06 & 0.01 & 0.17 & 0.04 & 0.01 & 0.14 \\
\hline CD at 5\% & 0.19 & 0.03 & 0.50 & 0.13 & 0.04 & 0.42 \\
\hline
\end{tabular}

FA - Fly ash, VC - Vermicompost, RDF - Recommended Dose of Fertilizer

Table 3: Effect of Fly Ash and Vermicompost at Different Combinations on Soil N, P and K (kg/ha)

\begin{tabular}{|c|c|c|c|c|c|c|}
\hline \multirow{3}{*}{ Treatments $(\mathbf{T})$} & \multicolumn{6}{|c|}{ N, P and K of Soil (kg/ha) } \\
\hline & \multicolumn{3}{|c|}{ Harvest-I } & \multicolumn{3}{|c|}{ Harvest-II } \\
\hline & $\mathbf{N}$ & $\mathbf{P}$ & $\mathbf{K}$ & $\mathbf{N}$ & $\mathbf{P}$ & $\mathbf{K}$ \\
\hline $\mathrm{T}_{1}-\mathrm{FA}+\mathrm{VC}(0 \mathrm{t} / \mathrm{ha}+10 \mathrm{t} / \mathrm{ha})$ & 414.61 & 29.32 & 302.33 & 372.42 & 21.56 & 289.65 \\
\hline $\mathrm{T}_{2}-\mathrm{FA}+\mathrm{VC}(1 \mathrm{t} / \mathrm{ha}+9 \mathrm{t} / \mathrm{ha})$ & 411.24 & 29.07 & 306.17 & 368.74 & 21.42 & 291.73 \\
\hline $\mathrm{T}_{3}-\mathrm{FA}+\mathrm{VC}(2 \mathrm{t} / \mathrm{ha}+8 \mathrm{t} / \mathrm{ha})$ & 405.72 & 28.68 & 314.84 & 365.12 & 21.38 & 297.65 \\
\hline $\mathrm{T}_{4}-\mathrm{FA}+\mathrm{VC}(3 \mathrm{t} / \mathrm{ha}+7 \mathrm{t} / \mathrm{ha})$ & 383.13 & 28.55 & 319.20 & 346.82 & 21.32 & 303.32 \\
\hline $\mathrm{T}_{5}-\mathrm{FA}+\mathrm{VC}(4 \mathrm{t} / \mathrm{ha}+6 \mathrm{t} / \mathrm{ha})$ & 382.65 & 28.53 & 328.22 & 340.62 & 21.24 & 311.47 \\
\hline $\mathrm{T}_{6}-\mathrm{FA}+\mathrm{VC}(5 \mathrm{t} / \mathrm{ha}+5 \mathrm{t} / \mathrm{ha})$ & 380.80 & 28.41 & 357.43 & 339.18 & 21.17 & 338.18 \\
\hline $\mathrm{T}_{7}-\mathrm{FA}+\mathrm{VC}(6 \mathrm{t} / \mathrm{ha}+4 \mathrm{t} / \mathrm{ha})$ & 380.26 & 28.15 & 383.25 & 336.46 & 21.12 & 368.93 \\
\hline $\mathrm{T}_{8}-\mathrm{FA}+\mathrm{VC}(7 \mathrm{t} / \mathrm{ha}+3 \mathrm{t} / \mathrm{ha})$ & 377.48 & 27.32 & 412.68 & 335.82 & 20.79 & 393.22 \\
\hline $\mathrm{T}_{9}-\mathrm{FA}+\mathrm{VC}(8 \mathrm{t} / \mathrm{ha}+2 \mathrm{t} / \mathrm{ha})$ & 377.03 & 26.64 & 458.12 & 332.72 & 20.49 & 443.28 \\
\hline $\mathrm{T}_{10}-\mathrm{FA}+\mathrm{VC}(9 \mathrm{t} / \mathrm{ha}+1 \mathrm{t} / \mathrm{ha})$ & 368.15 & 25.72 & 510.67 & 328.15 & 19.87 & 496.41 \\
\hline$T_{11}-F A+V C(10 t / h a+0 t / h a)$ & 354.73 & 24.19 & 558.25 & 324.52 & 19.04 & 542.13 \\
\hline $\mathrm{T}_{12}-\mathrm{RDF}(100-40-40 \mathrm{NPK} \mathrm{Kg} / \mathrm{ha})$ & 332.28 & 23.69 & 296.61 & 318.22 & 16.33 & 272.83 \\
\hline $\mathrm{T}_{13}-$ Zero fertilizer (control) & 282.11 & 19.08 & 278.35 & 272.11 & 13.48 & 265.46 \\
\hline SE m \pm & 6.57 & 0.66 & 13.34 & 5.52 & 0.62 & 7.96 \\
\hline CD at $5 \%$ & 19.29 & 1.94 & 39.17 & 16.22 & 1.84 & 23.39 \\
\hline
\end{tabular}

FA - Fly ash, VC - Vermicompost, RDF - Recommended Dose of Fertilizer

\section{REFERENCES}

1. Bhaisare, B. Matte, D.B. Badole, W.P. and Deshmukh, A. 2000. Effect of flyash on yield, uptake of nutrients and quality of green gram grown on vertisol. Journal of Soils and Crops. 10(1): 122-124.

2. Choudhary, R. Yadav, L.R. and Parihar, S. 2014. Studies on the interactive effect between Vermi compost and fertility levels on pearl millet (Pennisetum glaucum L.) Annals of Agri-Bio Research. 19(3): 430-433.

3. Dange, N.R. and Nalge, D.N. 2010. Effect of fly ash and FYM on yield of groundnut and nutrient concentration and uptake by groundnut in vertisol. Advance Research Journal of Crop Improvement. 1(2): 156-158.

4. Deshmukh A.S. Matte, D.B. and Kene, D.R. 2000. Effect of graded levels of fly ash and NPK on soil properties and yield of wheat. Journal of Soil and Crops. 10(2): 260-264.

5. Mittra, B.N. Karmakar, S. Swain, D.K. Ghosh, B.C. 2003. Fly ash-a potential source of soil amendment and a component of 


\section{Influenced by Fly Ash and Vermicompost}

integrated plant nutrient supply system. International Ash Utilization Symposium, Centre for Applied Energy Research, Kentucky University. 28. http:// www.Fly ash.info./2003/28 mit.pdf.

6. Pandu Sastry, K. Srinivas, K.V.N.S. Kumar, J.K. Kumar, A.N. Dharmendra, K.R. and Maheswara Sarma, V.U. 2014. Variation in the essential oil content and composition of citronella (Cymbopogon winterianus Jowitt.) in relation to time of harvest and weather conditions. Industrial Crops and Products. 61: 240-248.

7. Pandu Sastry, K. Srinivas, K.V.N.S. Kumar, J.K. Kumar, A.N. Dharmendra, K.R. and Anubala, A.S. 2015. Changes in the essential oil content and composition of palmarosa (Cymbopogon martini) harvested at different stages and short intervals in two different seasons. Industrial Crops and Products. 69: 348-354.

8. Rajeswara Rao, B.R. Rajput, D.K. and Patel, R.P. 2009. Essential oil profiles of different parts of palmarosa (Cymbopogon martini (Roxb.) Wats. Var. motia Burk.). Journal of Essential Oil Research. 21(6): 519-521.

9. Rai, A. Mishra, S. and Sharma, D.P. 2012. Effect of fly ash and sewage sludge on chemical properties of soil and yield of radish (Raphanus sativus). New Agriculturist. 23(1): 49-54.

10. Singh, M. and Wasnik, K. 2013. Effect of Vermi compost and chemical fertilizer on growth, herb, oil yield, nutrient uptake, soil fertility and oil quality of rosemary. Communications in Soil Science and Plant Analysis. 44(18): 2691-2700.

11. Verma, S.R. Shivran, A.C. Bhanwaria, R. and Singh, M. 2014. Effect of Vermi compost and sulphur on growth, yield and nutrient uptake of fenugreek (Trigonella foenumgraecum L.). The Bioscan. 9(2): 667-670.

12. Yavarzadeh, M.R. and Shamsadini, H. 2012. Safe environment by using flyash and Vermi compost on wheat. International conference on transport, Environment Civil Engineering. ICTECE' 2012, Kuala Lumpur, Malaysia, August 25-26. 
